\title{
IDENTIFICATION OF ROOT (WILT) DISEASED COCONUT PALMS BEFORE VISUAL SYMPTOM EXPRESSION
}

\author{
V. Rajagoval and B. Sumathykuttyamma*
}

\begin{abstract}
Determination of stomatal resistance (rs) and leaf water potential (?) were employed as techniques to distinguish coconut palms (Cocos nucifera L.) devoid of foliar symptoms ('apparently healthy') from those with symptorns of wilt disease viz. flaccidity, yellowing and necrosis ('wilt diseased'). Infected palms are characterized by low stomatal diffusive resistance and reduction in leaf water potential. Among the apparently healthy palms, some exhibited high rs and high ?, characteristic of truly healthy palms, while others had the trend similar to the 'wilt' diseased palms. The latter group of palms was considered as disease 'suspects' and was closely monitored for the symptom expression. In about 10 to 14 months, all the palms 'suspected' to be diseased had the visual symptoms of the disease.
\end{abstract}

\section{INTRODUCTION}

In Kerala State of South India, coconut palms in about 410,000ha are affected by a wilt disease, characterized by flaccidity or ribbing of leaflets as the main foliar symptom (Radha and Lal, 1972). As root decay is associated with the disease it is commonly referred to as root (wilt) disease, the word 'wilt' referring to the condition of the crown (Anonymous, 1981). Recent studies on the etiology of the disease have implicated mycoplasma-like organisms (MLOs), which have been identified in the root tips, leaf axils, inflorescence meristerns etc (Solomon, Govindankutty and Nienhaus, 1987). Another widely known MLO disease of coconut is lethal yellowing (LY) disease in Jamaica (Mc Coy, 1983).

Although caused by MLOs, the wilt disease of Kerala and LY disease of Jamaica differ not only in their symptoms but specifically in their water relations. While the LY affected palms exhibit closed stomata (Basham and Eskafi, 1980) in wilt diseased palms an abnormal stomatal opening was reported (Rajagopal, Patil and Sumathykuttyamma, 1986). Thus, the diseased palms of Kerala had low stomatal resistance compared to healthy palms, irrespective of their age, time of the day or season or soil water conditions. The loss of turgor potential in the leaves of these palms was found to be the cause for the characteristic flaccidity symptom (Rajagopal, Sumathykuttyamma and Patil, 1987 a).

*Central Plantation Crops Research Institute (CPCRI), Kudlu Post, Kasaragod, 670124 Kerala, India and CPCRI Regional Station, Kayarnkularn 690 533, Kerala India 
As the development of disease is slow, taking months or even years between the infection and expression of symptoms, tests were developed for the early detection of the disease (Joseph and Shantha, 1963, Dwivedi, Mathew, Ray, Sumathykuttyamma and Ninan, 1977, Solomon Sasikala and Shantha, 1983a and Rajagopal, Sasikala, Sumathykuttyamma, Chethpakam and Rawther, 1987b). Among these, the last paper compared two tests viz. serological and physiological Le stornatal resistance. Coconut palms with latent infection, but appearing to be healthy (devoid of symptoms) had positive serological reaction and low stomatal resistance, similar to palms with clear disease symptorns. The authors could show that it was possible to detect disease affected palms six to 20 months eartier than the manifestation of foliar symptoms. As leaf water potential has a direct relationship with the development of foliar symptorns (Rajagopal et al. 1978a), the present paper reports use of leaf water potential, besides the stornatal resistance, to detect latent infections in palms which appeared healthy.

\section{MATERIALS AND METHODS}

Coconut palms (Cocos nucifera L. var West Coast Tall), planted in the Institute Farm were utilized for the experiments. They were raised under a square $7.5 \mathrm{~m}$ spacing in randomized block design. The palms were fertilized with 500g urea, 320g P205 and 1200g K20 per tree per year in split closes. Diagnostic tests, based on the serological reaction and stomatal diffusive resistance, were conducted earlier (Rajagopal et al. 1987b) in five plots containing both diseased and apparently healthy palms. Present work was carried out in one of the plots.

At the time of the experiment in April-May 1984, there were 19 palms with clear symptoms of the disease, while 36 palms were free of foliar symptoms and thus considered as 'apparently healthy' palms. However, only nine out of 36 palms appeared to be really healthy, as revealed by serologically negative reaction and high stomatal resistance while the rest of 27 palms exhibited the trend similar to the diseased palms, hence clesignated as disease 'suspects' (Rajagopal et al 1987b). However, in the present study, nine healthy, 19 diseased and 16 'suspected' palms (where both the tests agreed) were subjected to leaf water potential measurements and compared with the stomatal resistance both initially (Table 1) and thrice during a two month period (Table 2).

Stomatal resistance and transpiration rate in the leaves were determined with the Steady State Porometer (Li-Cor 1600, Lamda Instruments, Nebraska, U.S.A) between 10.00h and 11.30h cluring dry season which was found to be the most appropriate time to distinguish between the healthy and diseased palms (Rajagopal et al. 1987a). The method standardized by Rajagopal et al. (1986) for measurements in coconut at different time of the day or season or soil condition was adopted. The first leaf was selected as it normally does not exhibit external symptoms of the disease, whereas the middle leaf was selected as it shows by typical flaccidity symptom. The method consisted of determination of diffusive resistance in two leafiets on the abaxial surface (hypostomatic type) of the lamina at five positions each along the leaflet on either side of the midrib. This method of determination of diffusive resistance in 'intact' and 'excised' leaflets was perfected earlier (Rajagopal, Mathew and Varkey, 1982), wherein the time course study revealed that the stomatal resistance increases rapidly only five to six minutes after the cutting of leaflets. However, for all the studies, the measurements were taken within minutes after excision which was found to be nearest to the values obtained with the intact system. The same timing was given for each sample and thus the reproducibility was achieved. Prior to each measurement, the micro climatic conditions like light., temperature and relative humidity near the experimental palms were also recorded with the porometer. Measurements were taken on a total of 44 palms on two consecutive days and four such determinations were undertaken within a span of two months.

The leaf water potential was measured simultaneously (using the opposite leaflets of the same leaf on which the stornatal resistance was determined) with a Scholander pressure chamber (Plant 
Water Console 3000, Soil Moisture Co., U.S.A) according to the method of Milburn and Zimmermann (1977) and followed earlier in root wilt disease by Rajagopal et al.(1987a). In this case also the measurements were completed within two minutes.

The experimental palms were monitored at intervals of two months for foliar symptoms using the disease index scoring method based on the flaccidity yellowing and necrosis developed by George and Radha (1973). According to this method the palms with less than disease index of 10 are considered as apparently healthy, while those with the index ranging from 11 to 25,26 to 50 and above 50 are designated as diseased early, middle and advanced respectively.

\section{RESULTS AND DISCUSSION}

At the start of the experiment 19 palms had visual symptoms of the disease and reacted positively to serological test and showed low stornatal resistance (Table 1). The foliar symptoms were absent in the other 25 palms, out of which only nine turned out to be free of latent infection (at that given time) based on serologically negative reaction and high stomatal resistance, both indicative of healthy nature of palms (Rajagopal et al. 1987a). There were 16 palms which had positive serological reaction and low stomatal resistance but still did not develop the foliar symptoms, hence designated as 'suspects'.

Both the first fully open leaf and the middle whorl leaf of the apparently healthy palms showed higher stornatal resistance with lower transpiration rate than the clearly diseased palms (Table 2). These changes in transpirational loss of water reflected on thew, which was consistently low in the infected palms. This is in conformity with earlier observations (Rajagopal et al. 1986 and 1987a). The nature of symptoms on the leaflets of different whorls of leaves i.e of different ages reflected the changes in ?. Although the most perceptible symptorns of disease viz. flaccidity occurred on the leaves of middle whorl, changes in ? had already begun in the younger spindle leaf and first whorls leaves (Rajagopal et al. 1987a). The initial changes associated with flaccidity, namely flattening and bending of the leaf tip could be seen on the first whorl, leaves, although it might have been initiated much earlier i.e when the leaves were, in unfolded condition (spindle leaves) with a time lag of about a month. This is supported by drastic fall in ? between the spindle leaf and first leaf stages. Thus it is evident that the changes in water relations had already started in plants not showing visible signs of the disease.

The time taken for the appearance of visual symptorns varies from palm to palm as indicated in Table 3. While it took 10 months for three palms to exhibit the symptoms, within the next two months to four months the remaining palms, nine and four respectively, also had developed the characteristic symptoms of the disease. The disease index of these palms ranged from $15 \%$ to $31 \% \mathrm{i}$. e. early to middle stage of the disease. The difference in the expression of disease symptoms in time and space was explained by Rajagopal et al. (1987b) on the basis of slow development of symptorns because of the perennial nature of the crop. The authors reported the time lag ranging from six to 20 months between the performance of diagnostic tests and manifestation of visual symptorns. The fact that four of the apparently healthy palms had also contracted the disease in about 12 to 14 months preceded by low stomatal resistance and) $\mathrm{V}$ between the 2 nd and $3 \mathrm{rd}$ months reveal that periodic diagnosis of palms would be beneficial in ascertaining the latent infection of the discase. Between the 8th and 9th month, two more palms, exhibited characteristic stomatal behaviour and by 26th month foliar symptoms appeared (data not shown in the table). A similar situation occured with three palms which were originally healthy showed typical responses to diagnostic tests, followed by symptom development subsequently (Rajagopal et al. 1987b). All these show that the changes in stomatal regulation preceded the foliar symptoms of the disease. 
The lethal yellow affected coconut palms, another MLO disease, exhibited closure of stomata (high stomatal resistance) and high xylem pressure potential (Mc Donough and Zimmermann, 1979, Matteoni and Sincalir, 1983), which is in contrast to the abnormal stomatal opening (low stomatal resistance) with low in wilt diseased palms (Rajagopal et al. 1986 and 1987a). The possible cause for this differential response of the same species of coconut palms, growing in different geographical regions, could be either due to the difference in the strains of MI-Os or to the nature of the metabolites produced in the tissues of the infected plants. Rajagopal et al. (1986) surmised the production of fusicoccin-like substances in the infected palms, as the abnormal opening of stomata is characteristic of fusicoccin treated plants (Turner and Graniti, 1976). This was strengthened by a preliminary study with a histological staining technique for locating $\mathrm{K}^{\prime}$ in guard cells under the fluroscent microscope, which revealed a relatively high content of K'in leaves with the flaccidity symptom (Rajagopal and Govindankutty, unpublished).

That the stomatal resistance measurements can be used to detect MLO-infected plants before visible symptoms was shown both in yellows disease (Basham and Eskafi, 1980, Matteoni and Sinclair, 1983) and wilt disease (Rajagopal et al. 1987b). In the case of apricot wilt disease caused by the fungus Cytospora cincta the determination of leaf conductance could also predict the wilt disease three months before the visual symptoms appeared (Korner, 1981). Leaf water potential measurements can also serve for early diagnosis of palms affected by MLOs was shown by Basham and Eskafi (1980) and supported by the present findings.

Coconut palms withlVin the range of -2.0 to $-2.5 \mathrm{MPa}$ under non-stressed conditions may be considered as wilt diseased or disease 'suspects', since the healthy palms had ? ranging from -1.2 to -1.5 MPa as reported in a previous paper (Rajagopal et al. 1987a) and elsewhere (Milburn and Davis, 1973, Milburn and Zimmermann, 1977). This is an agreement with the earlier findings that palms with very low stomatal resistance (ranging from 1.0 to $3.5 \mathrm{sec} . \mathrm{Cm}^{-1}$ ) and relatively high transpiration rate (7.0 to $13.9 \mathrm{ug} . \mathrm{Cm}^{-2} \mathrm{Sec}^{-1}$ ) are considered as clearly diseased palms (Rajagopal et al. 1986). Recently, Rajagopal, Ramadasan, Kasturibai and Balasimha (1988) had shown the meank ? of -1.4 MPa in the rainfed coconut palms, as against $-0.9 \mathrm{Mpa}$ - in the irrigated palm. Thus, it is possible to distinguish between the diseaseincluced and drought-induced changes in ? of coconut palms.

Generally the stomata should remain closed in response to the prevailing dry conditions if the palms are healthy. The fact that diseased palms fail to close their stomata in response to soil and atmospheric droughts show that damage was caused to the stomatat apparatus of the diseased palms. The controlling influence of stomata on the water balance of coconut palms was reported by Milburn and Zimmermann (1977) who suggested that the balance was more protected in the 'dry' than in the 'wet' season. Healthy coconut palms showed similar trend, while in the diseased palms the stomatal regulation was affected in both the seasons, though with greater magnitude in the 'dry' than in the 'wet' season (Rajagopal et al. 1986). According to the authors, the healthy palms develop a protective mechanism to regulate their water balance through an effective stomatal system, while this protective mechanism seems to have been greatly impaired in the palm affected by wilt disease. It is clear from the present study that the two parameters of water relations could compliment each other in cletecting the diseased palms prior to manifestation of visual symptoms. These early diagnostic tests are being employed for large scale field studies in the disease prevalent areas.

\section{ACKNOWLEDGEMENTS}

Our thanks are due Dr. N. P. Jayasnaker, Joint Director for the facilities and offer of valuable suggestions. 


\section{REFERENCES}

BASHAM, H.G. \& ESKAFI, F.M. (1980). Xylern transport in palms with lethal yellowing. Proceedings of 4th International Conference on Lethal Yellowing, Florida, Abstract 8.

DWIVEDI, R.S., MATHEW., RAY, P.K., SUMATHYKUTTYAMMA A,B. \& NINAN, S. (1977). Rapid biochemical test to detect root (wilt) disease of coconut. Current Science 46:611-612.

JOSEPH, T. \& SHANTHA,P. (1963). Studies on a colour test for the root (wilt) disease of coconut. 50th Indian Science Congress 3:618.

KORNER, C. (1981). Stomatal behaviour and water potentialin apricot with symptoms of wilt disease. Angew Botanik 55:469-476.

MATTEONI, J.A. \& SINCLAIR, W.A. (1983). Stomatal closure in plants infected with mycoplasma-like organisms. Phytopathology 73:398-402.

Mc COY, R.E. (1983). Lethal Yellowing of palms. Gainsville, University of Florida.

Mc DONOUGH, J. \& ZIMMERMANN, M.H. (1979). Effect of lethal yellowing on xylem pressure potential in coconut palms. Principes 23:132-137.

MILBURN, J.A. \& DAVIS, T.A. (1973). Role of pressure in xylem transport of coconut and other palms. Physiologia Plantarum 29:415-420.

MILBURN, J.A. \& ZIMMERMANN, M.H. (1977). Preliminary studies on sap flow in Cocos nucifera L. 1. Water relations in xylem transport. New Phytologist 79:535-541.

RADHA, K. \& LAL, S.B. (1972). Diagnostic symptoms of root (wilt) disease of coconut. Indian Journal of Agricultural Science 42:410-413.

RAJAGOPAL, V., MATHEW, C. \& VARKEY, T. (1982). Determination of stornatal resistance and transpiration in the leaves of coconut (Cocos nucifera L.) using the steady state porometer. Proceedings of the International Workshop on Special Problems in Physiological Investigations of Tree Crops - TREEPHYSINDIA'82. M.R. SETHURAJ, G.GURURAJARAO. \& A.S. RAGHAVENDRA (eds), Published by Rubber Research Institute of India, Kottayarn, pp. 100104.

RAJAGOPAL, V., PATIL, K.D. \& SUMATHYKUTTYAMMA, B. (1986). Abnormal stomatal opening in coconut palms affected with root (wilt) disease Journal of Experimental Botany 37:1398-1405.

RAJAGOPAL, V., SUMATHYKUTTYAMMA, B. \& PATIL, K.D. (1987a). Water relations of coconut palms affected with root (wilt) disease. New Phytologist 105:289-293.

RAJAGOPAL, V., SASIKALA, M., SUMATHYKUT- TYAMMA, B. CHEMPAKAM, B. \& RAWTHER, T.S. (1987b). Early diagnostic techniques on the root (wilt disease of coconut (India). Philippine Journal of Coconut Studies (accepted). 
RAJAGOPAL, V., RAMADASAN, A., KASTURIBAI, K.V. \& BALASIMHA, D.(1988). Influence of irrigation on leaf water relations and dry matter production in coconut palms. Irrigation Science (accepted).

SOLOMON, J.J., SASIKALA, M. \& SHANTHA, P. (1983a). A serological test for the detection of root (wilt) disease of coconut. In: Coconut Research and Development. N.M. NAYAR (ed), Wiley Eastern Limited, New Delhi, pp. 401405.

SOLOMON, J.J,. GOVINDANKUTTY, M.P. \& NIENHAUS, P. (1983b). Association of mycoplasma-like organisms with the root (wilt) disease of coconut in India. Zeitschkrift Pflanzenkrankheiten 90:295-297.

TURNER, N.C. \& GRANITI, A. (1976). Stornatal response of two almond varieties - to fusicoccin. Physiological Plant Patholog,y 9:1,75-182.

GEORGE, M.V. \& RADHA, K. (1973). Computation of disease index of root (wilt) disease of coconut. Indian Journal of Agricultural Science 43:366-370. 
Table 1: Condition of coconut palms at the start of the experiment in the first

Week April, 1984. Observations were recorded on serological reaction (spindle leaf) and stomatal resistance (middle leaf) from a total of 44 palms

\begin{tabular}{|c|c|c|c|c|}
\hline $\begin{array}{c}\text { No. of palms } \\
\text { Observed }\end{array}$ & Visual symptons & $\begin{array}{c}\text { Diagnostics tests } \\
\text { Serological } \\
\text { Reaction }\end{array}$ & $\begin{array}{c}\text { Stomatal } \\
\text { Resistance sec. } \\
\mathrm{cm}^{-1} \text { (range) }\end{array}$ & Remarks \\
\hline 9 & Absent & Negative & $5.8-9.1$ & $\begin{array}{c}\text { Apparently } \\
\text { Healthy } \\
\text { Diseased }\end{array}$ \\
19 & Present & Positive & $2.3-3.9$ & 'Suspects' \\
\hline
\end{tabular}

Table 2: Relationship between the stomatal function and leaf water potential in Coconut palms affected by root (wilt) disease. Stomatal resistance, rs $\left(\mathrm{sec} . \mathrm{cm}^{-1}\right)$, transpiration rate, $\operatorname{Tr}\left(\mathrm{ug} . \mathrm{cm}^{-2} \mathrm{sec}^{-1}\right)$ and leaf water potential. ? (MPa) were determined in the first fully open and middle whorl leaves during April-May 1984. Values are means of three determination (once in April and twice in May). \pm S.E. of the mean

\begin{tabular}{|c|c|c|c|c|c|c|}
\hline Palm condition & \multicolumn{3}{|c|}{ First leaf } & \multicolumn{3}{|c|}{ Middle leaf } \\
\hline $\begin{array}{c}\text { and no. of palms } \\
\text { observed }\end{array}$ & rs & $\operatorname{Tr}$ & $?$ & rs & $\mathrm{Tr}$ & $?$ \\
\hline Apparently healthy & 5.02 & 3.90 & -1.46 & 4.84 & 3.30 & -1.64 \\
\hline (9) & \pm 0.63 & 0.41 & 0.12 & 0.52 & 0.29 & 0.17 \\
\hline Diseased & 1.42 & 9.60 & -2.20 & 1.77 & 12.00 & -2.15 \\
\hline (19) & \pm 0.09 & 0.86 & 0.17 & 0.14 & 0.93 & 0.13 \\
\hline Disease 'suspects' & 2.47 & 7.40 & -2.01 & 2.14 & 7.80 & -2.24 \\
\hline (16) & \pm 0.11 & 0.58 & 0.20 & 0.18 & 0.66 & 0.28 \\
\hline
\end{tabular}

Table 3: Appearance of visual symptoms of root (wilt) disease in the disease 'suspects' (DS) and apparently healthy (AH) palms subjected earlier to diagnostic tests. Disease index was recorded at two montly intervals after the performance of the tests.

\begin{tabular}{|c|c|c|c|c|c|c|c|}
\hline \multirow{2}{*}{$\begin{array}{c}\text { No. of palms } \\
\text { Observerd }\end{array}$} & \multicolumn{7}{|c|}{ No. of palms with disease symptoms in months after tests } \\
\cline { 2 - 8 } & 2 & 4 & 6 & 8 & 10 & 12 & 14 \\
\hline 16 DS & Nil & Nil & Nil & Nil & 3 & 9 & 14 \\
& Nil & Nil & Nil & Nil & Nil & $3 *$ & $1 *$ \\
\hline
\end{tabular}

* These four palms had shown low stomatal resistance and ? between $2^{\text {nd }}$ and $3^{\text {rd }}$ month. 